\title{
RESILIENSI MASYARAKAT NELAYAN SELAMA MUSIM LAEB DI DESA PUGER KULON KECAMATAN PUGER KABUPATEN JEMBER
}

\author{
Wardatul Chamro*, Lenny Widjayanthi \\ Program Studi Agribisnis, Fakultas Pertanian, Universitas Jember \\ Jl. Kalimantan No. 37, Kampus Tegalboto, Jember, Jawa Timur \\ *Corresponding author: wardatulchamro15@gmail.com
}

\begin{abstract}
The laeb season struck some coastal areas in the southern part of Java that occurred as an impact of climate anomalies. This condition is experienced by the fishermen in Puger Kulon village, Puger sub-district, especially fishermen who catch Lemuru and Benggol fish due to the difficulties to get fish when the unsuitable sea conditions. This condition causes fishermen to experience difficulties in maintaining social resilience that can affect the lives of their families. The research aims to decide the resilience of the Jukung fishermen in the current laeb by formulating the utilization of livelihood assets to keep the lives of fishermen. The Data is collected using three methods, namely interviews, observations and documentation studies. The key informant is deliberately determined that Jukung fishermen and supporting informant are the wives of fishermen and the staff of TPI. The data is analyzed by using Miles and Huberman. The validity method uses triangulation and source techniques. The result show that 1) Jukung fishermen will resilien during the Laeb season when the Jukung fishermen can use their livelihood assets both in household assets as well as in the living system of Jukung fishermen. Livelihood assets consist of human capital, natural capital, physical capital, financial capital, and social capital. The fishermen need to reduce or minimize capital in certain conditions in order to resilient without causing a new burden and vulnerability for Jukung fishermen in Puger Kulon village.
\end{abstract}

Keywords: laeb, climate anomaly, Jukung fisherman, resilience

Abstrak: Musim laeb melanda di beberapa daerah pesisir bagian selatan Pulau Jawa
yang terjadi sebagai dampak adanya anomali iklim. Laeb ini dialami oleh nelayan
Jukung di Desa Puger Kulon Kecamatan Puger, khususnya nelayan menangkap jenis
ikan lemuru dan benggol yang kesulitan dalam mendapatkan hasil tangkapan dan
kondisi alam lautan yang tidak mendukung kegiatan penangkapan ikan. Kondisi ini
dapat mendorong nelayan mengalami kesulitan dalam mempertahankan ketahanan
sosial (resiliensi) yang mempengaruhi kehidupan keluarganya. Penelitian ini bertujuan
untuk mengetahui resiliensi nelayan Jukung selama menghadapi musim laeb agar
dapat merumuskan kegiatan pemanfaat modal livelihood asset secara efektif untuk
mempertahankan kehidupan nelayan. Daerah penelitian ditentukan secara sengaja
yaitu Desa Puger Kulon Kecamatan Puger dan menggunakan pendekatan kualitatif.
Data diambil menggunakan 3 metode yaitu wawancara, observasi dan studi
dokumentasi. Key informant ditentukan secara sengaja yakni nelayan Jukung dan
informan pendukung adalah istri nelayan dan staf dari TPI Puger. Data dianalisis
menggunakan Miles and Huberman. Metode keabsahan menggunakan triangulasi
teknik dan sumber. Hasil penelitian menunjukkan bahwa masyarakat Jukung akan
resilien selama musim laeb apabila nelayan Jukung dapat memanfaatkan livelihood
assets mereka baik dalam aset rumah tangganya maupun dalam sistem nafkah nelayan 
Jukung. Livelihood assets ini terdiri dari dari modal manusia, modal alam, modal fisik, modal finansial, dan modal sosial. Nelayan perlu memilah modal yang seharusnya tidak perlu atau diminimalkan penggunaannya dalam kondisi-kondisi tertentu agar tetap resilien tanpa membuat beban dan kerentanan baru untuk nelayan Jukung di Desa Puger Kulon.

Kata kunci: musim laeb, anomali iklim, resiliensi, nelayan Jukung

\section{PENDAHULUAN}

Keluarga nelayan pada umumnya memiliki persoalan yang lebih kompleks dibandingkan dengan keluarga pertanian. Keluarga nelayan memiliki siklus khusus dibandingkan keluarga petani. Ciri khusus keluarga nelayan ialah penggunaan wilayah pesisir dan lautan sebagai produksi. Kegiatan produksi ini dilakukan dengan cara penangkapan ikan di laut. Penangkapan ikan di laut sangat memiliki resiko. Peralatan yang digunakan dalam proses penangkapan ikan pun harus sesuai dengan situasi dan kondisi. Kondisi laut yang sedang pasang ini, menyebabkan nelayan berada pada ketidakpastian jam dan hari dalam bekerja. Misal, dalam 30 hari kerja, nelayan hanya dapat bekerja selama 20 hari saja, dikarenakan pada 10 hari berikutnya terjadi gelombang tinggi, maka pada waktu tersebut nelayan dikatakan menganggur. Kondisi alam yang tidak menentu mengakibatkan pendapatan yang diperoleh sedikit atau tidak memperoleh hasil sama sekali seperti yang terjadi saat tidak musim ikan (Wijayani, 2016). Salah satu penyebab kondisi alam yang tidak menentu yaitu adanya anomali iklim di berbagai wilayah Indonesia.

Anomali ini mengakibatkan perubahan iklim global yang tidak menentu. Dampak dari perubahan iklim global adalah terjadinya fenomena $\mathrm{El}$ Nino (meningkatnya suhu samudera pasifik) dan La Nina (menurunnya suhu samudera pasifik) yang mempengaruhi samudera-samudera di seluruh dunia. Terjadinya fenomena tersebut mengakibatkan suhu permukaan air laut berubah, sehingga mempengaruhi pola kehidupan ikan yang tidak hanya mengakibatkan penurunan, tetapi juga pergeseran populasi spesies ikan ke laut yang lebih dingin atau bergeser ke wilayah yang lebih panas (Moegni et al., 2014). Selain itu, anomali menyebabkan perubahan cuaca tidak terduga di lautan.

Dampak dari adanya fenomena anomali iklim yang terjadi di berbagai wilayah di sepanjang pantai selatan Jawa ini, paling rentan akan dialami oleh masyarakat pedesaan khususnya pada masyarakat pesisir. Salah satu desa yang mengalami anomali iklim adalah Desa Puger Kulon Kecamatan Puger yang berada di Kabupaten Jember karena nelayan merupakan pekerjaan mayoritas penduduk desa ini. Banyaknya jumlah nelayan menggambarkan bahwa ketergantungan masyarakat pada hasil laut sangatlah besar, sedangkan kondisi laut yang saat ini mengalami anomali iklim mengakibatnya penurunan jumlah ikan di lautan dan perubahan cuaca tak terduga dapat menyebabkan nelayan khususnya Jukung yang menggunakan kapal kecil mengalami kesulitan dalam memperoleh hasil tangkapan yang sangat rendah dan berkurangnya hari kerja mereka. Masalah ini secara langsung mempengaruhi pendapatan nelayan yang terus menurun sehingga mereka kesulitan untuk memenuhi kehidupan seharihari, pendidikan anak dan jaminan kesehatan keluarga. Upaya yang harus dilakukan oleh nelayan agar mampu untuk ketahanan (resiliensi) mereka adalah dengan beradaptasi.

Adaptasi yang dilakukan oleh masyarakat nelayan pada setiap daerah berbeda-beda karena adanya perbedaan pada pengaruh dari kondisi anomali iklim dan dampak yang ditimbulkan pada masyarakat yang memiliki kegiatan berbasis perikanan laut. Besar kecilnya perbedaan ini menjelaskan sensitivitas kelompok masyarakat, sehingga perlu diketahui cara mempertahankan ketahanan sosial (resiliensi) komunitas nelayan dalam menghadapi bencana perubahan iklim. (Wahyono et al., 2014).

Resiliensi dalam menghadapi suatu krisis dapat dipahami sebagai kemampuan rumah tangga tersebut untuk kembali ke kondisi normal. Resiliensi pada rumah tangga berhubungan dengan strategi nafkah. Menurut Speranza et al. (2014), resiliensi nafkah mengacu pada kapasitas nafkah untuk melindungi dari tekanan dan gangguan. 
Resiliensi nafkah dicirikan dengan aset dan strategi aktor untuk mempertahankan dan meningkatkan aset. Sebuah nafkah dikatakan merupakan lenting jika dapat mempertahankan fungsi utama (makanan, pendapatan, jaminan, mengurangi kemiskinan dll) dan dapat menahan dampak gangguan tanpa menyebabkan penurunan produksi dan kesejahteraan. Aset tersebut dikenal dengan istilah livelihood assets. Ellis (2000), menjelaskan bahwa livehood asset atau strategi nafkah adalah mata pencaharian terdiri dari aset (alam, manusia, fisik finansaial, dan modal sosial), kegiatan, dan akses masuk (dimediasi oleh lembaga dan hubungan sosial) yang bersama-sama menentukan hidup yang diperoleh oleh individu atau rumah tangga, sedangkan diversifikasi mata pencaharian pedesaan didefinisikan sebagai proses dimana rumah tangga pedesaan membangun sebuah portofolio yang semakin beragam dengan kegiatan dan aset dalam rangka untuk bertahan hidup dan untuk meningkatkan standar hidup mereka.

Musim laeb sebagai dampak dari anomali iklim yang terjadi menuntut nelayan Jukung untuk melakukan penyesuaian diri atau beradaptasi pada kondisi perubahan iklim yang tidak menentu dengan membuat langkahlangkah tertentu untuk mempertahankan kehidupan (resiliensi) nelayan dalam konteks nafkah rumah tangga. Nelayan perlu mengurangi ancaman kelangsungan hidup dan mengeksplorasi kesempatan-kesempatan yang menguntungkan. Oleh karena itu, permasalahan yang hendak dikaji dalam penelitian ini adalah resiliensi masyarakat nelayan selama musim laeb di Desa Puger Kulon Kecamatan Puger Kabupaten Jember.

Penelitian ini bertujuan untuk mengetahui resiliensi nelayan Jukung selama musim laeb berlangsung sebagai dampak dari anomali iklim agar peneliti dapat merumuskan kegiatan pemanfaat modal livelihood asset secara efektif untuk mempertahankan kehidupan nelayan.

\section{METODE PENELITIAN}

Penentuan daerah penelitian dengan purposive method (Sugiono, 2013). Daerah yang dijadikan lokasi penelitian merupakan Desa Puger Kulon berdasarkan pertimbangan bahwa desa ini merupakan desa dengan jumlah nelayan terbesar di Kecamatan Puger pada data dua tahun terakhir. Selain itu, Desa Puger Kulon merupakan salah satu wilayah pesisir yang mengalami musim laeb selama anomali iklim berlangsung.

Metode penelitian yang digunakan dalam penelitian ini adalah metode deskriptif kualitatif (Wibowo, 2011). Metode penentuan informan yang dilakukan pada penelitian ini adalah purposive sampling. Purposive sampling adalah salah satu metode pengambilan informan yang umum digunakan terutama dalam penelitian kualitatif. informan utama atau kunci adalah nelayan juragan Jukung dan pandego Jukung. Keduanya merupakan orang yang melakukan kegiatan penangkapan ikan menggunakan kapal Jukung dan alat tangkap jaring. Kedua pihak tersebut, diharapkan mampu memberikan gambaran secara jelas terkait resiliensi nelayan Jukung selama musim laeb berlangsung. Informan pendukung juga disebut sebagai informan eksternal. Informan eksternal ini meliputi staf TPI Puger dengan pertimbangan bahwa beliau mengetahui kondisi sosial masyarakat nelayan dan dampak anomali iklim yang membuat laeb dialami nelayan di desa Puger Kulon sehingga memahami cara nelayan agar tetap mampu dalam kondisi resilien. Informan pendukung juga melibatkan Istri dari nelayan terkait agar dapat mendukung pernyataan serta kelengkapan informasi yang didapatkan dari informan kunci yang telah ditentukan sebelumnya mengenai resiliensi yang dilakukan oleh keluarga nelayan Jukung

Teknik pengumpulan data yang dilakukan dalam penelitian ini terdiri dari beberapa teknik yaitu wawancara, observasi, dan studi dokumentasi. Analisis data dalam penelitian kualitatif, dilakukan pada saat pengumpulan data berlangsung, dan selesai pengumpulan data dalam periode tertentu. Miles dan Huberman dalam Sugiono (2016), mengemukakan bahwa aktivitas dalam analisis data kualitatif dilakukan secara interaktif dan berlangsung secara terus-menerus sampai tuntas, sehingga datanya sudah jenuh. Aktivitas data yaitu: reduction, data display dan conclusion drawing/verification. Uji keabsahan data yang digunakan dalam penelitian ini yaitu menggunakan triangulasi. Menurut Sugiyono (2013), triangulasi dalam pengujian kredibilitas ini diartikan sebagai pengecekan data dari 
berbagai sumber dengan berbagai cara dan berbagai waktu. Dengan demikian terdapat tiga teknik dalam triangulasi yaitu triangulasi sumber, triangulasi teknik pengumpulan dan waktu. Uji keabsahan data yang akan digunakan pada penelitian ini yaitu triangulasi teknik dan sumber

\section{HASIL DAN PEMBAHASAN}

Walker et al. (2004), mendefinisikan resiliensi adalah kemampuan sistem untuk menyerap gangguan dan mereorganisasi saat menjalani perubahan sehingga masih mempertahankan fungsi dasarnya. Resiliensi nafkah dipandang sebagai kemampuan untuk menghadapi guncangan atau krisis ekonomi sehingga masih dapat bertahan hidup, masih dalam posisi yang stabil, tidak mengalami keterpurukan yang berkepanjangan, dan kelaparan. Bentuk dari resiliensi tersebut beragam sesuai dengan sumber daya yang dimiliki. Mayunga pada tahun 2007 dalam penelitiannya menjelaskan bahwa resilensi akan berkaitan dengan pendekatan stategi nafkah berkelanjutan. Pendekatan strategi nafkah terdiri dari modal sosial finansial, manusia dan fisik dianggap sebagai faktor penetuan resilensi. Berikut ini merupakan gambaran mengenai modal-modal yang akan digunakan dalam penelitian ini.
Berdasarkan Tabel 1 dapat kita ketahui bahwa nelayan Jukung menggunakan livelihood asset agar tetap resilien. Setiap modal dalam livelihood asset ini dapat dimanfaatkan secara berbeda-beda sesuai dengan status kepemilikan, bentuk modal, dan jumlah asetnya. Peneliti membagi pemanfaatan livelihood asset menjadi aset yang dimiliki dalam rumah tangga nelayan dan asset yang dimiliki nelayan dalam nafkah nelayan. Hal ini dilakukan peneliti untuk mempermudah penjelasan dalam pemanfaat setiap aset modal nelayan sehingga diharapkan informasi yang didapatkan dari informan akan lebih lengkap. Pada aset rumah tangga peneliti juga menjadikan istri nelayan sebagai informan pada penelitian ini dengan pertimbangan bahwa aset rumah tangga nelayan tidak hanya bersumber dari yang dimiliki oleh pihak suami saja, istri juga memiliki modal-modal yang digunakan untuk membantu keluarganya agar tetap bisa resilien.

Pemanfaatan modal-modal asset nelayan berasal dari aset rumah tangga dan sistem nafkah. Kedua terbagi menjadi 5 modal yaitu modal alam, manusia, fisik, finansial dan sosial. Bentuk pemanfaatan livelihood asset nelayan Jukung di Desa Puger Kulon adalah sebagai berikut:

Tabel 1. Resiliensi Masyarakat Nelayan Jukung di Desa Puger Kulon

\begin{tabular}{|c|c|c|}
\hline Modal & Aset Rumah Tangga & Sistem Nafkah \\
\hline Alam & Menjual tanah beserta rumah & $\begin{array}{l}\text { b. Memanfaatkan pulau-pulau kecil dan } \\
\text { daratan sebagai tempat perlindungan saat } \\
\text { menghadapi cuaca buruk di lautan } \\
\text { c. menangkap jenis ikan lain saat lemuru } \\
\text { sedang laeb }\end{array}$ \\
\hline Manusia & $\begin{array}{l}\text { a. Memanfaatkan pendidikan anak } \\
\text { b. Memanfaatkan keterampilan lain dari } \\
\text { nelayan dan istri } \\
\text { c. Memanfaatkan tenaga yang dimiliki }\end{array}$ & $\begin{array}{l}\text { a. Memanfaatkan pengetahuan dasar nelayan } \\
\text { tentang pola musim dan ikan tangkapannya }\end{array}$ \\
\hline Fisik & $\begin{array}{l}\text { a. Menjual atau menggadaikan sepeda } \\
\text { motor, sepeda, perabotan rumah tangga. } \\
\text { b. Menjual atau digadai perhiasan emas }\end{array}$ & $\begin{array}{l}\text { a. Menjual peralatannya, } \\
\text { b. memanfaatkan infrastruktur } \\
\text { pelabuhan dan TPI. }\end{array}$ \\
\hline Finansial & $\begin{array}{l}\text { a. Menggunakan uang tabungan untuk } \\
\text { kebutuhan hidup keluarga dan modal } \\
\text { kerja }\end{array}$ & $\begin{array}{l}\text { a. Membeli alat/mesin untuk disimpan dan } \\
\text { dijual saat membutuhkan uang }\end{array}$ \\
\hline Sosial & $\begin{array}{l}\text { a. Meminta bantuan dalam bentuk bahan } \\
\text { makanan dan uang tunai secara gratis } \\
\text { atau dengan dihutangkan oleh keluarga, } \\
\text { teman dan tetangga } \\
\text { b. Memanfaatkan kepercayaan }\end{array}$ & $\begin{array}{l}\text { a. Menghindari jaringan sosial dan asas } \\
\text { kepercayaan } \\
\text { b. Bekerjasama dengan berdiskusi saat cuaca } \\
\text { buruk terjadi }\end{array}$ \\
\hline
\end{tabular}

Sumber : Data primer, 2018 


\section{Modal Alam \\ Modal Alam dalam Aset Rumah Tangga}

Modal alam dalam aset keluarga nelayan merupakan aset yang dimiliki oleh nelayan maupun keluarganya yang dapat dimanfaatkan dalam kondisi terdesak selama menghadapi dampak dari anomali iklim. Keluarga nelayan Jukung baik juragan maupun pandhego yang ada di Desa Puger Kulon memiliki ekonomi yang cukup sulit sehingga sangat sulit ditemui nelayan Jukung yang memiliki tanah untuk kegiatan persawahan karena tanah yang mereka miliki merupakan tanah yang berada dibawah bangunan rumah mereka, sehingga dalam penelitian ini, tanah berserta rumah peneliti anggap sebagai modal alam yang dimiliki oleh keluarga nelayan. Modal alam ini dapat dimanfaatkan oleh keluarga nelayan dengan cara menjualnya. Pemanfaatan modal alam dengan cara menjual rumah yang dilakukan oleh salah satu informan yaitu Bapak Baharudin sebagaimana yang diungkapkan dibawah ini:

"Pernah punya, itu pun punya orang tua tapi kita gak ikut modal. Terus dijual warisan rasa kos-kosan, Rp.6.600.000. Uang $e$ digawe kehidupan sehari-hari, terpakai kebutuhan" (Baharudin Harahap, 12 April 2018)

Menjual rumah merupakan keputusan yang sangat besar yang diambilnya, sehingga dalam pelaksanaanya Beliau berdiskusi terlebih dahulu. Pemanfaatan modal ini merupakan alternatif yang jarang dan tidak dimanfaatkan oleh nelayan Jukung lain. Pemanfaatan modal alam jarang dilakukan karena rumah merupakan salah satu kebutuhan dasar manusia, namun kondisi yang peneliti temui di lapang terjadi kerena saat musim laeb, ikan tangkapan sedang sepi, dan cuaca di lautan yang tidak mendukung sehingga kesulitan mendapatkan penghasilan untuk memenuhi kebutuhan rumah tangganya.

\section{Modal Alam dalam Nafkah Nelayan}

Modal alam dalam nafkah nelayan Jukung lebih luas dibandingkan dengan yang dimiliki dalam aset keluarganya. Modal alam dalam nafkah nelayan di penelitian ini merupakan aset-aset yang di alam disekitar kawasan pantai dan lautan tempat nelayan Jukung Desa Puger
Kulon Kecamatan Puger mencari nafkah. Modal ini dapat dimanfaatkan oleh seluruh nelayan Jukung baik untuk juragan maupun yang hanya bekerja sebagai pandhego karena modal ini dimanfaatkan selama kegiatan penangkapan ikan berlangsung.

Modal alam yang dimanfaatkan dalam sistem nafkahnya adalah berupa pemanfaatan pulau-pulau kecil seperti Nusa Barong dan daratan terdekat seperti Watu Ulo sebagai tempat perlindungan saat menghadapi cuaca buruk yang tidak dapat diprediksi selama kegiatan penangkapan ikan berlangsung. Hal ini sesuai dengan pernyataan oleh semua informan. Berikut merupakan salah satu contoh dari pernyataan tersebut:

"Cuaca mbe badai, kalo ombak kan sekilas. Kalau di laut ada badai, gak akan aman sebelum kita menepi dipinggir biasanya memanfaatkan pulau-pulau kecil, kalau disini itu nusa barong" (Baharudin Harahap, 12 April 2018)

Selain itu, ketika produksi ikan lemuru berkurang drastis bahkan tidak ada di laut Puger dan sekitarnya, nelayan Jukung dapat memanfaatkan jenis ikan lainya yang tersedia di lautan Puger dan sekitarnya. Jenis ikan tangakapan lainnya yaitu nener atau benur (bayi lobster) yang memiliki resiko tinggi sebagai kegiatan ilegal, namun terdapat nelayan yang memilih agar tetap aman dengan menangkap ikan-ikan karang seperti kerapu, kakap merah, ikan tuna dan udang terasi. Pernyataan ini diungkapkan oleh seluruh informan penelitian. Contoh pernyataan yang akan disajikan berasal dari 3 informan berikut:

"Kalau sepi mancing ikan, ikan karang, ikan kerapu, ikan kakap merah. Dulu pernah benur berjaya tapi kan gak aman gak berani. Gak aman, kan ilegal kan rame lagi berhenti lagi jadi mending ikan karang. Hasil e gak mesti kalo banyak yaa Rp.50.000, Rp.70.000" (Baharudin Harahap, 12 April 2018)

"Enggeh mboten wonten. Sak niki nopo seng wonten. Nangkep ikan tuna, sak iki kadang urang. Urang trasi iku seng lembut. Pernah ikut lobster, kan aku anak buah e mayang kan perahu mboten terikat mbak saya. Tapi 
saya mengutamakan yang ikut mayang biasa. (Edi Susanto, 12 April 2018)

"Kalau laeb itu ikan itu ikan ndak ada, itu kalau laeb itu lain maksudnya jenisnya lain. Kalau sekarang saya cari ikan itu urang, kalau nenerkan dilarang sekarang." (Kusman, 19 Mei 2018)

Nelayan Jukung Desa Puger Kulon melakukan adaptasi untuk mengurangi musim laeb karena adanya dari anomali iklim dengan memanfaatkan modal alam. Modal alam yang dimanfaatkan dalam sistem nafkahnya adalah berupa pemanfaatan pulau-pulau kecil dan daratan sebagai tempat perlindungan saat menghadapi cuaca buruk di lautan. Selain itu, ketika produksi ikan lemuru berkurang drastis bahkan tidak ada di laut Puger dan sekitarnya, nelayan Jukung dapat memanfaatkan jenis ikan lainya yang tersedia di lautan Puger dan sekitarnya sehingga nelayan tetap mendapat penghasilan dalam sektor perikanan.

\section{Modal Manusia}

Modal Manusia dalam Aset Rumah Tangga

Modal manusia dalam aset rumah tangga merupakan modal yang paling potensial untuk dimanfaatkan. Modal manusia dapat terdiri dari pendidikan, keterampilan, dan tenaga yang dimiliki oleh keluarga nelayan Jukung yang dapat dimanfaatkan untuk menambah penghasilan keluarga nelayan. Pemanfaatan anggota kelurga setiap nelayan berbeda-beda sesuai dengan anggota keluarganya.

Memomobilitas keluarga nelayan Jukung Desa Puger Kulon untuk bekerja, baik anak mupun istri merupakan salah satu bentuk pemanfaatan modal manusia dalam aset rumah tangga. Berdasarkan hasil di lapang terdapat 1 nelayan yang memanfaatkan anaknya untuk membantu ekonomi keluarga dengan bekerja di luar sektor perikanan. Selain memanfaatkan anak, terdapat 3 nelayan yang memanfaatkan bantuan istrinya yang masing-masing istrinya bekerja menjadi pedagang makanan, pedagang kebutuhan pokok sembako, dan bekerja sebagai pembantu rumah tangga. Bantuan yang diterima nelayan dengan adanya keterlibatan anggota keluarga untuk bekerja sangat besar dirasakan oleh nelayan informan. Berikut adalah salah satu contoh pernyataan dari informan.
"Ini saya ini kan kerjanya dibantu istri jadi kekurangan ini dibantu istri. Kalau dari dulu saya tidak dibantu istri kurang, bukan cuma kurang ya gak makan itu 2 tahun gak ono opo-opo. Ya 2 tahun kalau istri gak kerja di pasar ya mau makan apa. Seumpama gak ada sampinganne angel. Kalau sekarang ya agel. Ngepenno laut gak cukup. Istri jualan di pasar, nracang. Jualan bumbu-bumbu. Kalau gak ada itu entah. Kalau kehabisan modal itu ya hehe, Kalau disini lautnya gak ada penghasilan pasarnya sepi juga (Kusman, 19 Mei 2018)

Terakhir, yaitu pemanfaatan ketrampilan. Pemanfaatan keterampilan di luar kegiatan penangkapan ikan sangat membantu nelayan selama musim laeb.Hal ini dibuktikan oleh 2 informan, ketika mereka tidak dapat melakukan kegiatan penangkapan ikan, mereka mampu untuk tetap aktif bekerja sehingga tetap mendapatkan penghasilan. Sebagai contoh yang ditemui di lapangan yaitu memanfaatkan keterampilan untuk bertukang dan tenaga untuk menjadi kuli bangunan di ice strorage. Kegiatan-kegiatan yang dilakukan oleh nelayan sebagai cara mereka beradaptasi menjaga kelangsungan hidup sesuai dengan salah satu pola stategi Corner (1988) dalam buku yang ditulis oleh Kusnadi (2000) bahwa mereka beraneka ragam pekerjaan untuk memperoleh penghasilan. Pekerjaan-pekerjaan yang tersedia di desa dan dapat merendahkan martabat pun akan tetap diterima, kendapatipun upahnya rendah. Ganjaran atau balasan berupa pangan membuat suatu pekerjaan menjadi lebih menarik.

Memanfaatkan modal manusia yang dimiliki oleh keluarga nelayan merupakan langkah yang paling tepat. Pemanfaatan ini merupakan satu langkah adaptasi postif agar selama anomali iklim berlangsung mereka dapat tetap resilien. Berdasarkan kondisi yang ada di lapang dapat diketahui bahwa nelayan Jukung Desa Puger Kulon yang mampu memaksimalkan penggunaan modal manusia aset keluarga akan memiliki resiliensi yang lebih baik dibandingkan yang tidak melakukannya.

Modal Manusia dalam Sistem Nafkah

Modal manusia dalam sistem nafkah nelayan yang paling berperan adalah pendidikan. 
Pendidikan nelayan umumnya bersumber dari pembinaan atau penyuluhan dari pihak terkait, namun berdasarkan informasi sebelumnya telah diketahui bahwa mereka belum pernah mendapatkannya, sehingga dalam penelitian ini modal manusia adalah pengetahuan dasar nelayan. Nelayan Jukung Desa Puger Kulon memahami kondisi yang sedang mereka hadapi saat ini. Memanfaatan pengetahuan dasar mereka untuk memprediksi cuaca dan pola tangkapan ikan saat ini kurang dapat diandalkan karena lebih meleset dibanding sesuai. Berdasarkan hal tersebut, maka pemanfaatan modal manusia berupa pengetahuan dasar kurang dapat bahkan tidak dapat diandalkan saat anomali iklim berlangsung.

\section{Modal Fisik \\ Modal Fisik dalam Aset Rumah Tangga}

Modal Fisik sejatinya merupakan aset ekonomi, sehingga pada penelitian ini modal fisik dalam aset rumah tangga diukur berdasarkan kepemilikan aset nelayan Jukung yang dapat mendukung perekonomian rumah tangga. Pemanfaatan modal fisik yang dimiliki oleh keluarga nelayan juragan Jukung Desa Puger Kulon akan berbeda dengan nelayan yang hanya bekerja sebagai pandhego kapal Jukung. Nelayan juragan Jukung memiliki kehidupan yang lebih baik dibandingkan dengan pandhego, sehingga barang-barang yang dijual atau gadaikan biasanya berupa barang-barang bernilai ekonomis tinggi, sedangkan nelayan pandhego hanya menjual barang-barang sederhana. Modal fisik yang digunakan oleh nelayan Jukung Desa Puger Kulon terdiri dari sepeda motor, sepeda, perabotan rumah tangga, serta perhiasan emas. Pemanfaatan dengan cara menjual atau digadai dapat dijadikan salah satu alternatif agar keluarga nelayan tetap dapat memenuhi kebutuhannya tanpa harus menambah beban hutang keluarganya.Selain barang-barang tersebut, dalam kasus yang ekstrim terdapat nelayan yang menjual peralatan dan baju bekas yang dimiliki untuk memenuhi kebutuhan hidup.

\section{Modal Fsisik dalam Nafkah Nelayan}

Modal fisik dalam nafkah nelayan adalah barang-barang produksi dan infrastruktur yang diperlukan untuk mendukung mata pencaharian nelayan Jukung Desa Puger Kulon. Barang- barang produksi ini berupa alat-alat tangakap dan mesin yang digunakan nelayan Jukung untuk menangkap ikan di laut. Berdasarkan informasi yang didapatkan peneliti, barangbarang produksi hanya dimiliki oleh nelayan juragan saja, karena nelayan juragan wajib mengeluarkan modal untuk melakukan kegiatan penangkapan, sedangkan pandhego hanya mengandalkan keterampilan yang dimilikinya.

Peralatan yang dimiliki oleh nelayan Jukung Desa Puger Kulon, tergolong sederhana sehingga anomali iklim terjadi perlatan ini tidak dapat membantu nelayan Jukung untuk mengurangi dampak yang dirasakan, satusatunya cara pemanfaatan modal fisik berupa barang produksi saat mendesak adalah dengan menjualnya. Hal ini sesuai dengan pernyataan dari 2 informan yang pernah menjual jarring setet kecil dan jarring rusak kepada petani padi.

Pemanfaatan modal fisik tidak hanya dilakukan nelayan dengan cara menjual peralatan kerjanya, namun juga dapat dilakukan dengan memanfaatkan infrastruktur yang ada di Puger, yakni berupa Pelabuhan dan TPI Puger. Manfaat yang diterima bisa beragam, dan bisa saja berbeda antara nelayan juragan dan pandhego. Kesamaan manfaat yang dirasakan oleh keduanya dengan adanya pelabuhan sebagai tempat untuk menyandarkan kapal dan informasi mengenai kondisi iklim terkini agar dapat mengurangi resiko kerugian dan kematian. Semua nelayan sepakat bahwa informasi ini sangat bermanfaat. Saat peneliti melakukan observasi di Pelabuhan, masih terdapat satu cara lagi yang dapat digunakan nelayan untuk mengetahui informasi terkini yakni dengan melihat selebaran yang ditempal pada pos penjaga, namun di lapang nelayan lebih banyak melihat salah satu cara yaitu melihat running text yang diletakkan diatas selebaran dari forcast.com paling sering digunakan nelayan, karena tulisannya yang besar dan bisa dilihat dari kejauhan selama nelayan bersiap melaut menjadi alasan utamanya, meskipun sebagian nelayan juga melihat informasi melalui bendera. Berdasarkan informan pendukung yaitu Staf TPI Puger, bendera yang berada di pinggir dermaga akan diganti warna benderanya sesuai kondisi sebagai peringatan tanda bahaya. Berikut ini merupakan gambar dari bentuk informasi yang bisa diakses oleh nelayan di pelabuhan dan dermaga. 


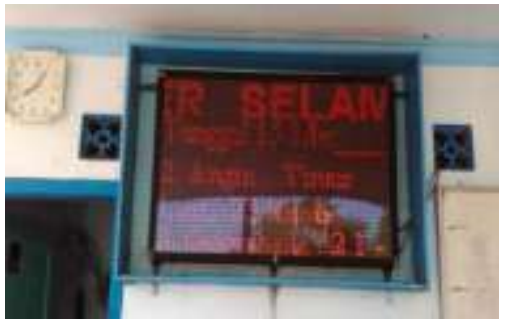

Gambar a

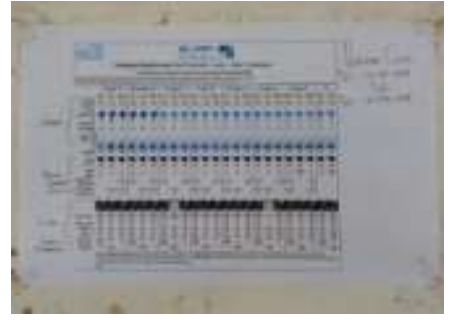

Gambar b

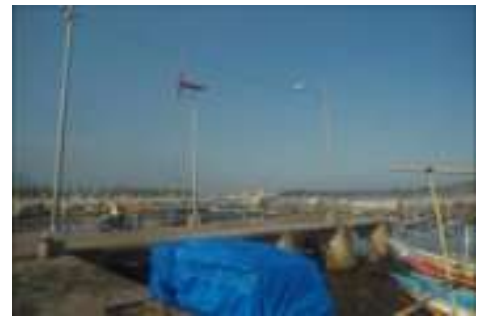

Gambar c

Keterangan:

Gambar a : Running Text Berisi Ramalan Kondisi Iklim Laut Terkini

Gambar b : Ramalan Kondisi Iklim Terkini dari Forcast.Com yang Ditempel di Pintu Masuk Pelabuhan

Gambar c : Bendera Penanda Bahaya di Dermaga Pelabuhan Puger

Fasilitas yang ada di pelabuhan tidak hanya dimanfaatkan oleh nelayan saja, lokasi sekitar pelabuhan dan dermaga biasanya dimanfaatkan oleh pedagang. Fasilitas ini secara tidak langsung sangat membantu nelayan Jukung, terutama yang bekerja sebagai pandhego. Hal ini sesuai dengan pernyataan yang diungkapkan oleh Bapak Baharudin Harahap dan Bapak Edi Susanto berikut:

"Yaa terbantu sekali. Kadang kita kan ada semacam bonus untuk pandhego kita jual beli sendiri yaa TPI. Kan penjualnya banyak. Ada yang asongan, ada yang pengepul. TPI itu lokasi tempat pelelangan ikan. Gak jalan lelang e, kan sangking banyaknya pengambek. Lak biyen cuma seng gede-dege lha saiki" (Baharudin, 12 April 2018)

"Dari tempat, tempat lebih luas. Kalau dulu kan kecil mbak, didol dewe bisa, lak jatah itu kan kalau di TPI banyak pedagang itu bisa dijual disitu (Edi Susanto, 12 April 2018)

Berdasakan pernyataan tersebut dapat diketahui bahwa saat hasil yang diperoleh nelayan Jukung melimpah, juragan Jukung biasanya akan memberikan bonus ikan kepada pandhegonya. Ikan ini bisa dibawa pulang untuk keluarganya, namun juga bisa dijual. Jika pandhego lebih memilih untuk menjual ikan tersebut, maka mereka akan memanfaatkan keberadaan pedagang asongan yang akan mendekati mereka begitu mereka turun dari Jukung, namun ada pula yang menjual ikannya kepada pedagang disekitar pasar ikan di pelabuhan.

\section{Modal Finansial \\ Modal Finansial Aset Rumah Tangga}

Modal fisik merupakan modal yang merujuk pada persediaan uang tunai yang dapat diakses untuk membeli barang konsumsi atau produksi, dan akses pada kredit dapat dimasukkan ke dalam kategori ini (Ellis, 2000). Modal finansial yang digunakan dalam penelitian ini tidak diwujudkan berupa uang tunai yang ada di tangan nelayan, namun uang tersebut dalam bentuk simpanan atau tabungan. Simpanan atau tabungan yang dimiliki oleh keluarga nelayan yang dapat dimanfaatkan nelayan untuk memenuhi kebutuhan keluarga maupun untuk modal kerja. Keluarga nelayan melakukan penyimpanan dengan cara yang berbeda-beda yang me reka sesuaikan dengan kondisi ekonomi mereka dan kemudahan akses mereka untuk menabung, namun tabungan yang paling umum dilakukan adalah berupa tabungan emas dan uang. Hal ini dapat dilihat berdasarkan pernyataan-pernyataan yang diberikan informan.

"Berupa tabungan karo mas-masan. Lak pas musim iku yo tuku emas tapi lak pas barat teko yowes didol. Nabung uang pernah, tapi ndak sampe akeh entek. Nyeleh digae budalan nyeleh digae budalan pas entek gak sampe bayari tabungan entek wes tabunganne, koyok saiki entek" (Junaidi, 27 Maret 2018)

Berdasarkan keseluruhan pernyataan informan utama dan pedukung yang telah 
peniliti kumpulkan dapat diketahui bahwa selama perubahan cuaca ekstrim ini mempengaruhi populasi ikan dilautan yang turun secara drastis atau lebih dikenal dengan istilah laeb oleh nelayan Jukung sekitar. Kondisi seperti ini sangat disadari oleh nelayan Jukung sehingga saat musim panen berlangsung atau saat nelayan memperoleh penghasilan lebih, maka nelayan akan menyimpan uang tersebut berupa emas dan tabungan yang untuk digunakan sebagai persediaan saat tangakapan sepi dan cuaca buruk terus terjadi. Nelayan menggunakan uang tabungan maupun hasil penjualan emas untuk kebutuhan hidup keluarga dan modal kerja nelayan Jukung merupakan salah satu bentuk usaha mempertahankan resiliensi nelayan Jukung dengan memanfaatkan modal finansial keluarga

\section{Modal Finansial Sistem Nafkah}

Modal finansial dalam aset rumah tangga nelayan terdiri dari uang yang ditabung oleh keluarga nelayan, sedangkan dalam sistem nafkah dilakukan dengan menyimpan uang dalam bentuk peralatan tangkap. Pembelian alat ini sengaja dilakukan karena ingin menyimpan uangnya berupa perlatan. Hal ini hanya dilakukan oleh nelayan juragan saja, selama penelitian berlangsung hanya 1 infroman yang memberikan pernyataan bahwa pemanfaatan modal finansial yang dimiliki dilakukan dengan cara tersebut. Cara ini memiliki kesamaan dengan konsep yang ada pada modal fisik, perbedaanya, hanya niat yang dilakukan. Jika pada modal fisik barang-barang produksi memang dibeli karena kebutuhan, pada modal finansial barang ini sengaja dibeli untuk menyimpan uang dapat bentuk barang produksi.

\section{Modal Sosial \\ Modal Sosial dalam Aset Rumah Tangga}

Modal sosial merupakan modal terakhir dalam rangkaian livelihood asset. Modal ini merujuk pada jaringan sosial dan asosiasi di mana orang berpartisipasi, memperoleh dukungan yang memberikan kontribusi terhadap penghidupan mereka (Ellis, 2000). Berdasarkan hal tersebut, maka dalam penelitian ini modal soial terdiri dari jaringan sosial yang dimiliki oleh keluarga nelayan baik keluarga dan teman dari suami atau istri serta tetangga sekitar lingkungan tempat tinggal keluarga nelayan yang dapat membantu penghidupan nelayan Jukung selama musim laeb berlangsung. Modal sosial yang paling banyak dimanfaatkan didapat atas jaringan sosial keluarga. Hal tersebut sesuai dengan pernyataan dari informan utama yang menyatakan bahwa tidak ada penghasilan yang bisa digunakan untuk memenuhi kebutuhan hidup keluarganya, bantuan dari pihak keluarga sangat membantu penghidupannya. Bantuan dapat berupa barang pokok dan uang tunai secara gratis atau meminjam. Keluarga menjadi orang yang akan dimintai tolong pertama dibandingkan jaringan sosial lainnya karena keluarga biasanya tidak memaksakan untuk dikembalikan dalam jarak waktu yang dekat. Selain itu, alasan mereka tidak memanfaatkan jaringan teman dan tetangga karena dinilai bahwa selama laeb berlangsung, maka seluruh masyarakat nelayan Desa Puger Kulon akan mengalami nasib yang sama. Pernyataan yang diberikan oleh para informan utama, dikonfirmasi ulang oleh informan pendukung, yang salah satunya adalah sebagai berikut:

"Jaringan sosial e seng sering memanfaatkan keluarga dari suami. Lak konco sering lek Am. Mbalekne yo nyicil sak hasil e iku da, pokok hasil oleh yo bayar yo Rp.50.000, yo Rp.20.000, paling gede Rp.100.000 wes. Kadang yo nyeleh sampe Rp.1.000.000 digawe bondo modal sak berangkatan iku. Lak iku yo langsung bayar kontan yo tapi diklumpokno disek. Diklumpokne dewe disek baru bayar" (Amsiah, 27 Maret 2018)

Berdasarkan pernyataan tersebut dapat diketahui bahwa selain nelayan menggunakan jaringan keluarga juga adanya perbedaan pemanfaatan modal sosial antara nelayan Jukung. Perbedaan itu terletak pada jaringan sosial yang dimanfaatkan, meskipun suami (nelayan) mereka tidak dapat menggunakan jaringan pertemanan, sebagai istri mereka dapat memanfaatkan teman mereka untuk meminjam uang. Selain memanfaatkan jaringan pertemanan dengan meminjam uang, istri nelayan juga dapat memanfaatkan kepercayaan yang dibangun dengan teman berupa pemetokan arisan tanpa undian atau dimenangkan secara sengaja. 
Pemanfaatan modal sosial beruapa jaringan sosial adalah upaya yang dilakukan nelayan Jukung Desa Puger Kulon untuk mengurangi kesulitan dalam memenuhi kebutuhan sehari-hari, mengurangi ketergantungan dengan pihak patron. Jaringan sosial ini dimanfaatkan dengan cara meminta bantuan dalam bentuk bahan makanan dan uang tunai secara gratis atau dengan dihutangkan serta memanfaatkan kepercayaan. Jaringan sosial keluarga merupakan jaringan sosial yang paling banyak dimanfaatkan, selain jaringan teman, dan tetangga.

\section{Modal Sosial dalam Sistem Nafkah}

Modal sosial dalam sistem nafkah nelayan dalam penelitian ini terdiri dari jaringan sosial, kepercayaan dan kerjasama yang terbangun pada lingkup mata pencaharian nelayan Jukung. Jaringan sosial ini didapat dari pengambek, maupun dengan juragan atau pandhego yang bekerja bersamanya. Kerjasama dalam penelitian ini merpakan kekompakan antara nelayan juragan dan pandhego nya dalam menghadapi cuaca yang buruk saat kegiatan penangkapan ikan sedang berlangsung di laut.

Nelayan Jukung biasanya memanfaatkan jaringan sosial dan dasar kepercayaan dengan pengambek untuk mendapatkan pinjaman modal kerja. Hutang yang diberikan dapat berjumlah besar dengan syarat nelayan harus menjual hasil tangkapnya hanya kepada pengambek atau dapat dijual kepada pedagang pengepul dibawah pengawasan pengambek. Apabila nelayan tidak mematuhi peraturan tersebut, maka nelayan akan mendapatkan tekanan untuk segera membayar hutang tanpa melihat kondisi keuangan nelayan, sedangkan apabila mereka menurutinya mereka akan dibebaskan waktu pembayaran, dan dianggap lunas apabila barang yang dibeli dengan uang pinjaman rusak selama melaut atau peminjam meninggal dunia. Hal ini sesuai dengan yang diungkapkan oleh Bapak Junaidi dan Bapak Kusman berikut ini:

"Ke pengambek. lek anu enek kebutuhanne ape kerjo gak enek modal Rp.500.000, coro ngko ono hasil gede bayar. Wajib bayar, ono tulisanne. Kalo dijual ikan tetep. Gak iso, lak entuk setitik iku oleh sekilo rongkilo iku oleh dijual langsung, ngko lak $50 \mathrm{~kg}$ opo sakwintal iku di pengambek" (Juanidi, 27 Maret 2018)

"Alat-alat dikek I modal disek kan ngene waktu itu kan gak ada utang di pengambek" (Kusman, 19 Mei 2018)

Pemanfaatan dengan dasar yang sama juga dapat dilakukan oleh pandhego kepada nelayan juragan. Dua dari informan utama yang bekerja sebagai nelayan pandhego mengungkapkan bahwa saat keluarganya mengalami kesulitan untuk memnuhi kebutuhan sehari-hari dan kebutuhan yang bersifat mendadak, pandhego akan memanfaatkan jaringan sosial dan kepercayaan dengan juragannya. Peminjaman yang ini biasanya dilakukan dengan jumlah yang besar karena pada umumnya untuk juragan Jukung Desa Puger Kulon ada yang dapat meminjami uang sampai dengan sepuluh juta rupiah, terutama nelayan juragan Jukung bermodal besar, namun konsekuensi yang harus diterima adalah ikatan yang mewajibkan pandhego hanya bisa bekerja dengan jurgannya saja tanpa bisa ikut menjadi pandhego lepas yang bisa juragan lain jika tidak diberikan ijin. Jika hutang tersebut sudah lunas maka ikatan antara pandhego dan juragannya terlepas, sehingga nelayan pandhego dapat memilih untuk bekerja dengannya atau dengan juragan lain sewaktuwaktu apabila dinilai lebih menguntungkan dibanding ikut melakukan penangkapan ikan dengan juragan tersebut. Hal ini sesuai dengan pernyataan Bapak Baharudin dan Bapak Edi Susanto sebagai berikut:

"Pinjem ke juragan, masuk buku besar. Belum bayar, nambah-nambah iya, daripada minjem ke orangkan harus sekarang juga kan bayarnya kan, tapi kalo ke juragan selama kita masih ikut uangnya ndak masalah, kan kalo ke temen, ke saudara kan ada saatnya untuk mengembalikan, lak iku kan kita kembalikannya kalo kita mau keluar. Kita mau pindah, mau berhenti jadi biar gak bisa ikut lainnya, kecuali juraganne enggak berangkat, baru kita bisa ikut lainnya. Sekarang pun boleh dikembalikan tapi wedi kan orang e masih ikut, maksudte kalo sudah lunas orang e bisa pindah, bisa memilih kan. Pinjem e gak ada maksimal, endak kalo Jukung lewat dari 10 malu lah, 
gak umum kalo Jukung sampe 10" (Baharudin Harahap, 12 April 2018)

"Juragan pernah dulu saya. Besar mbak jumlahnya jutaan. Saya dulu pernah pinjem ke juragan Rp.3.500.000. Bayar kalau dari hasil itu gak ada pengurangan pokoknya harus bekerja, waktu kerja harus bekerja. Kalau sudah lunas bebas mau bekerja apa ndak, tapi kalau punya udah punya utang ya kudu ikut. Terikat. Kalau untuk bayar gak ada tekanan kamu harus bayar, pokoknya kalau pas kerja harus ikut kerja tapi angel mbak ate bayar juragan" (Edi Susanto, 12 April 2018

Modal sosial yang ada dalam sistem nafkah yang juga dapat dimanfaatkan adalah kerjasama antara nelayan juragan dan pandhego kapal Jukung Desa Puger Kulon terjadi dalam bentuk diskusi. Diskusi ini penting untuk dilakukan karena menentukan keselamatan dan keberlangsungan hubungan kerja mereka. Nelayan juragan umumnya merupakan orang yang menentukan kemudi kapal, namun mereka menyadari bahwa mereka tidak bekerja sendiri, jika hanya mengandalkan ego dan ambisi mereka untuk tetap melakukan penangkapan ikan selama cauaca buruk berlangsung maka hal ini akan mengancam hubungan kerja dengan pandhegonya dan bisa mengancam jiwa keduanya. Diskusi yang dilakukan nelayan juragan dan pandhego dapat menghindarkan nelayan Jukung dari masalah tersebut. Nelayan Jukung juga mengungkapkan bahwa diskusi hanya terjadi pada kapal Jukung dan tidak dilakukan oleh kapal besar.

Berdasarkan hasil wawancara yang dilakukan peneliti kepada informan diketahui bahwa nelayan Jukung memanfaatkan modal manusia berupa jaringan sosial, kepercayaan, dan kerjasama, Pemanfaatan modal sosial dalam sistem nafkah berupa jaringan sosial dan kepercayaan merupakan hal yang sensitif, karenanya hal tersebut masuk kedalam faktor penentu kerentanan nelayan Jukung Desa Puger Kulon. Hal ini dikarenakan sistem hutang dapat mengikat nelayan juragan dengan pangambek dan pandhego dengan juragannya. Meskipun menjadi salah satu faktor penyebab kerentanan, memanfaatkan modal sosial ini dapat dijadikan alternatif terbaik saat nelayan Jukung dan pandhego sedang membutuhkan uang dalam jumlah besar, dan tidak dapat membayar utang tersebut dalam waktu dekat, namun jika uang yang dibutuhkan dalam jumlah kecil, peneti lebih menyarankan nelayan Jukung untuk menggunakan jaringan sosial yang ada pada modal sosial dalam aset rumah tangga saja karena dengan meminjam atau meminta bantuan kepada jaringan sosial yang dimiliki pada aset rumah tangga, terutama keluarga, nelayan Jukung tidak memiliki sistem ikatan yang dapat merugikan nelayan Jukung. Selain itu,peneliti juga menyimpulkan bahwa modal sosial berupa kerjasama nelayan juragan dan pandhegonya merupakan bentuk adapatasi positif yang harus dilakukan oleh nelayan Jukung agar tetap resilien.

\section{Pendekatan Strategi Nafkah dalam Resiliensi Nelayan Jukung}

Resiliensi merupakan adaptasi positif yang bertujuan agar komunitas nelayan Jukung di Desa Puger Kulon dapat mempertahankan kehidupannya. Resiliensi dapat diukur dengan beberapa cara salah satunya menggunakan pendekatan strategi nafkah. Stategi nafkah dipilih oleh peneliti karena memiliki keuanggulan dibandingkan dengan pendekatan lainnya. Keunggulan dari strategi nafkah adalah lebih efektif dan relavan untuk mengurangi kemiskinan nelayan, bersifat sustainable sehingga dikenal dengan istilah adaptasi berkelajutan karena pegembangan asset dilakukan dengan cara mendayagunakannya selama tidak memberikan resiko dan ancaman. Stategi ini dilakukan dengan cara memanfaatkan aset modal mereka (livelihood asset). Modal-modal yang dapat digunakan nelayan Jukung agar tetap resilen oleh peneliti disajikan dalam tabel 2.

Berdasarkan Tabel 2 diketahui bahwa terdapat modal-modal yang dapat digunakan agar nelayan menjadi resilien dan terdapat modal yang seharusnya tidak dimanfaatkan. Modal yang dapat dimanfaatkan terdiri dari Modal Alam dan Sistem Nafkah, Modal Manusia dalam Aset Rumah Tangga, Modal Fisik pada Aset Rumah Tangga dan Modal Finansial dalam Aset Rumah Tangga, serta Modal Sosial pada Aset Rumah Tangga dan Sistem Nafkah nelayan Jukung Desa Puger Kulon. 
Wardatul C., Lenny W. : Resiliensi Masyarakat Nelayan Selama Musim Laeb ...

Tabel 2. Pemanfaatan Modal Livelihood Assets pada Resiliensi Strategi Nafkah

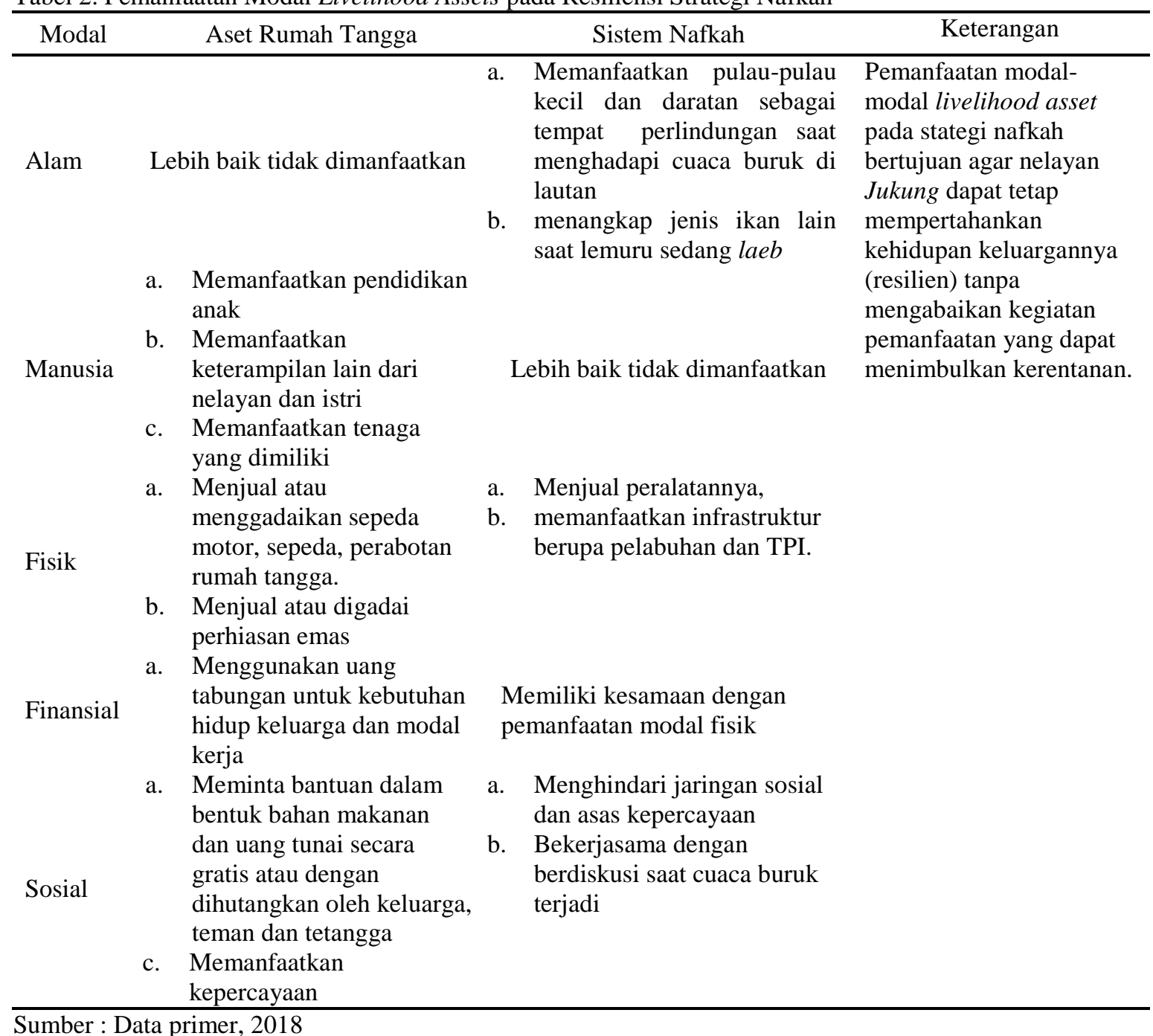

Modal-modal yang perlu tidak dimanfaatkan terdiri dari Modal Alam dalam Aset Rumah Tangga, Modal Manusia dalam Sistem Nafkah, dan adanya kesamaan pada Modal Finansial Sistem Nafkah dengan Modal Fisik, dan pada Modal Sosial Sistem Nafkah terdapat satu kegiatan yang harus tidak dimanfaatkan dan kegiatan lainnya dianggap bermanfaat. Modalmodal yang dapat dimanfaakan akan membantu nelayan untuk mempertahan hidupnya sehingga nelayan Jukung Desa Puger Kulon tetap dalam kondisi yang resilien meskipun sedang mengalami dampak dari anomali iklim. Modal yang sebaiknya tidak dimanfaatkan dipilih peneliti karena dianggap kurang memberikan dampak upada nelayan dan terdapat modal yang memberikan dampak buruk jangka panjang untuk nelayan Jukung.

\section{KESIMPULAN DAN SARAN}

Nelayan Jukung Desa Puger Kulon Kecamatan Puger Kabupaten Puger dalam kondisi yang resilien apabila dapat memanfaatkan livelihood asset yang mereka miliki dalam rumah tangga maupun dalam sistem nafkah nelayan Jukung, meskipun terdapat beberapa pemanfaatan modal yang seharusnya tidak dimanfaatkan. Modal-modal yang dapat dimanfaatkan dalam rumah tangga nelayan terdiri dari modal manusia, modal fisik, modal finansial, dan modal sosial, sedangkan dalam sistem nafkah nelayan modal-modal yang dapat dimanfaatkan terdiri dari modal alam, modal fisik, modal finansial yang memiliki kesamaan pemanfaatannya dengan modal fisik, serta kerjasama pada modal sosial. Modal yang seharusnya tidak dimanfaatkan oleh nelayan 
Jukung terdiri dari modal alam, modal manusia, dan modal sosial yang ditunjukan dengan menghindari jaringan sosial dan asas kepercayaan. Modal tersebut tidak dimanfaatkan agar nelayan Jukung dapat resilien selama anomali iklim berlangsung tanpa harus menambah beban dan kerentanan mereka.

Berdasarkan kesimpulan tersebut, peneliti memberikan saran untuk anggota keluarga nelayan baik untuk yang masih dalam usia sekolah maupun telah memasuki usia produktif sebaiknya menambah agar tetap mendapatkan penghasilan dengan bekerja di luar bidang perikanan (off fishing). Nelayan Jukung sebaiknya meminimalkan peminjaman uang kepada pangambek untuk mengurangi ketergantungan dan kerugian akibat ikatan hutang dengan pengambek serta menggunakan uang secara bijak dan sisa penghasilan dapat digunakan untuk menabung. Pemerintah sebaiknya bekerjasama dengan pihak TPI Puger dan PTS Puger untuk melakukan penyuluhan kepada nelayan Jukung agar memiliki motivasi untuk membangun kelembagaan dan mengaktifkan sistem pelelangan di TPI Puger.

\section{DAFTAR PUSTAKA}

Ellis, F. 2000. Rural Livelihoods and Diversity in Developing Countries. UK: Oxford University Press.

Kusnadi. 2000. Nelayan: Strategi Adaptasi dan Jaringan Sosial. Yogyakarta: LKIS.

Mayunga, J. S. 2007. Understanding and Applying The Concept of Community Disaster Resilience: A Capital-based Approach. Working Paper Prepared for The Summer Academy, Megacities as Hotspots of Risk: Sosial Vulnerability and Resilience Building, Munich, Germany, 22 - 28 Juli 2007.

Moegni, Nurtjahja, Ahamd, R., dan Gigih, P. 2014. Adaptasi Nelayan Perikanan Laut Tangkap dalam Menghadapi Perubahan Iklim. Ekonomi dan Studi Pembangunan, 15 (2), $182-189$.

Speranza, C., I., Wiesmannm, U., dan Rist, S. 2012. An Indicator Framework for Assessing Livelihood Resilience In The Context of Sosial-ecological Dynamics. Global Environmental Change, 28 (1), $109-119$.

Sugiyono. 2013. Metode Penelitian Kuantitatif Kualitatif dan $R \& D$. Bandung: Alfabeta.

Sugiyono. 2016. Metode Penelitian Kuantitatif Kualitatif dan $R \& D$. Bandung: Alfabeta

Wahyono, Ari, Masyhuri, I., dan Ibnu, N. 2014. Resiliensi Komunitas Nelayan dalam Menghadapi Perubahan Iklim: Kasus Di Desa Grajagan Pantai, Banyuwangi, Jawa Timur. Masyarakat dan Budaya, 16 (2), $259-274$.

Walker, B., Holling, C.S., Carpenter, S.R., and Kinzig, A. 2004. Resilience, Adaptability and Transformability In Socialecological Systems. Ecology and Society, 9 (2), 5.

Wijayani, Fika. 2016. Strategi Keluarga Nelayan dalam Mengatasi Kemiskinan. Skripsi. Jurusan Pendidikan Luar Sekolah Fakultas Ilmu Pendidikan Universitas Yogyakarta. Yogyakarta.

Wibowo, 2011. Cara Cerdas Menulis Artikel Ilmiah. Jakarta: Kompas Media Nusantara. 